\title{
References
}

ACG/VBB, 1975: Lokalisering af vandkraftressourcer på Grønlands vestkyst. Arctic Consultant Group and Vattenbyggnadsbyrån, Lyngby \& Stockholm, 58 pp.

Clement, P. 1980: Glaciologiske undersøgelser i Johan Dahl Land, Vestgrønland 1979. Unpubl. int. GGU report, $63 \mathrm{pp}$.

Olesen, O. B. \& Weidick, A. 1978: Glaciological investigations in Johan Dahl Land 1978. Unpubl. int. GGU report, $109 \mathrm{pp}$.

\section{Modelling glacier hydrology in West Greenland}

\author{
Roger J. Braithwaite
}

There is great interest in the possibility of using runoff in West Greenland for the generation of hydroelectric power. However, there is still very little information about hydrological conditions in the country. For example, measurements of runoff and glacier mass balance were only started at a few sites in the late 1970 s by the GTO and GGU, respectively. This means that the choice of any particular basin for possible exploitation must be made initially in the absence of direct field data. However, a solution to the problem is to develop a runoff model which can be applied to ungauged basins, i.e. a model which does not require field calibration. Such a model should give, as a minimum, estimates of the long-term mean runoff and the likely year-to-year variability. These estimates can be used to calculate hydropower potential and reservoir size at the feasibility or preliminary design stage of any proposed project. Naturally, if it is decided that a particular project is feasible, field measurements will then be started on-site for as many years as possible so that the final design of the project can be based upon a series of real data.

\section{Present work}

The current project started in May 1979. At present, the work is concerned with modelling specific values of precipitation, evaporation and glacier mass balance on a regional scale in West Greenland, so that specific runoff can be calculated from the water balance equation. In turn, total runoff can then be computed by multiplying the specific runoff by the appropriate basin area, e.g. as in Weidick \& Olesen (1980). Climatological data obtained from coastal weather stations are used in the models in combination with parameters and assumptions which are either guesses or are taken from other areas.

Three models have been worked out so far:

(1) A regional runoff model for West Greenland assuming that all glaciers have zero mean balance (Braithwaite, 1980a). 
(2) A regional ablation model for West Greenland (Braithwaite, 1980b).

(3) A runoff model for Johan Dahl Land using a more advanced version of the ablation model (unpublished).

The first two regional models are based upon the 1965-1974 records of precipitation and temperature respectively at 17 weather stations on the west coast of Greenland (operated by the Danish Meteorological Institute). For models (1) and (3) the precipitation is assumed to be uniformly distributed within basins and equal to the precipitation at the coast whilst the evaporation is guessed. The ablation in model (2) is calculated from extrapolated degree-day factors taking account of the 'glacier cooling effect' of Braithwaite (1977) and using the ablation-temperature parameter found by Braithwaite (in press). However, the model does not take account of the nature of the ablating surface while the more advanced model (3) attempts, in a primitive way, to take account of meltwater retention within the snow cover. Neither model (2) nor (3) can yet take account of 'land heating effect' between the coast and Inland Ice edge.

The theoretical shortcomings of the present three models are freely admitted. Although there are still few mass balance or runoff data from Greenland, the limited available data have been used in checking the models. As may be expected, some discrepancies have been found. For example, although both models (2) and (3) agree fairly well with ablation measurements on the tongue of Nordbogletscher (Olesen \& Weidick, 1978; Clement, 1980) they overestimate the total runoff from the Nordbosø basin as measured since 1976.

Continuation and extension of the field studies on the Nordbogletscher and on Qamanârssûp sermia will give data which can both check and help to improve the models. In particular, measurements of specific balance in the accumulation area, superimposed ice formation and within-basin variations of temperature, precipitation, and evaporation are urgently needed. The present models have at least served a useful heuristic purpose in identifying these needs.

\section{Outlook}

If proper coordination is maintained between modelling and fieldwork it should be possible to achieve the goal of an adequate runoff model for ungauged basins in West Greenland within a few years. By that time, the focus of hydrological work in Greenland should have shifted to the problem of making final designs of hydroelectric projects in basins where 5 to 10 years of measurements are available. It will be necessary then to model shorter period variations in runoff for optimizing project design.

\section{References}

Braithwaite, R. J. 1977: Air temperature and glacier ablation - a parametric approach. Unpublished Ph. D. thesis, McGill University, $146 \mathrm{pp}$.

Braithwaite, R, J. 1980a: A simple model of runoff from ungauged basins in West Greenland. Unpubl. int. GGU report, $35 \mathrm{pp}$.

Braithwaite, R. J. 1980b: Regional modelling of ablation in West Greenland. Rapp. Grønlands geol. Unders. 98, 20 pp.

Braithwaite, R. J. in press: On glacier energy balance, ablation and air temperature, J. Glaciol. 
Clement, P. 1980: Glaciologiske undersøgelser i Johan Dahl Land, Vestgrønland 1979. Unpubl. int. GGU report, 63 pp.

Olesen, O. B. \& Weidick, A. 1978: Glaciological investigations in Johan Dahl Land 1978. Unpubl. int. GGU report, $109 \mathrm{pp}$.

Weidick, A. \& Olesen, O. B. 1980: Hydrological basins in West Greenland. Rapp. Grønlands geol. Unders. 94, 51 pp.

\title{
Status of the West Greenland Glacier Inventory 1980
}

\author{
Anker Weidick
}

A first attempt at a regional assessment of water resources in West Greenland was made by Weidick \& Olesen $(1978,1980)$ with compilation of a basin inventory. It comprises an identification and coding system together with basic physiographic parameters and estimates of water balance elements for a total of 870 basins lying between the west coast and the Inland Ice and extending up to latitude $71^{\circ} \mathrm{N}$. A rough assessment of the total water balance of West Greenland $\left(484000 \mathrm{~km}^{2}\right)$ was made whereby $157 \mathrm{~km}^{3}$ of water are retained on the Inland Ice out of a total annual precipitation of $217 \mathrm{~km}^{3}$, while the net ablation of the Inland Ice contributes about $60 \mathrm{~km}^{3}$ to the annual runoff and $97 \mathrm{~km}^{3}$ are lost due to calving.

\section{Glacier inventory}

It was soon realized that the glaciological information contained in the basin inventory required expansion and refinement. Accordingly, it was decided to compile a glacier inventory according to internationally agreed guidelines (UNESCO/IAHS, 1970; TTS, 1977) in co-operation with the World Glacier Inventory project.

In the project area there are about 270 lobes of the Inland Ice and between $10^{3}$ and $10^{4}$ separate local glaciers and larger perennial snow patches. Topographic maps are available on a scale of 1:250 000 supplemented by a fairly good coverage of photographs. The coding of the glaciers is based upon basin areal divisions made by Weidick \& Olesen (1980) with minor changes to include glaciers which are not connected to well-defined hydrological basins. Measurements of glacier areas are now being made within the GGU using a TEKTRONIX graphic system. However, there is a special problem in delineating individual ice streams of the Inland Ice, especially higher up, so that the areal data for individual lobes may be quite unreliable, although errors should compensate for sector and district areal totals. There is a further problem that the surface drainage patterns, inferred from the maps and photographs, may not reflect the correct sub-glacial drainage patterns.

In addition to the numerical coding of the physiographic parameters of ice features ac- 